\title{
Alternative energy Resources from coal to wind
}

I n the past few years, we have been barraged with the news of rising energy prices and extreme instability in the areas where our energy is located. You have to be wondering if there is a better way. This article hopes to show that there is. The Web is full of sites on energy, from the basics to the ultrafantastic. For each energy source I have tried to nd one site that is a good, solid representation of that type of energy. My bias (or perhaps emphasis), whenever it appears, is in regards to an energy source s usefulness in transportation.

Astronaut Edgar Mitchell has noted that there are three phases to achieving a vision: awareness, education, and action. I hope that this article serves at least as a rst step. I also hope that it can lead to the second step, making readers aware that there are lots of ways to solve our energy-related problems. My goal for this article is that it will be both informative and entertaining. Enjoy the ride.

\section{The basics}

\section{Coal}

Coal is quite abundant in the U.S.; we have as much coal as Saudi Arabia has oil.

World Coal Institute. The World Coal Institute Web site discusses coal s role in future energy use. Access: http://www.wcicoal. com/web/bl_content.php?menu_id $=0.0$

United Mine Workers of America: What Coal Miners Do. This site includes illustrations of the various types of mines and how coal is extracted. Access: http://www. umwa.org/mining/colminrs.shtml.

\section{Coalgas}

One solution to the fuel problem is to just make our own. Coalgas is a synfuel (synthetic fuel) made from mostly coal. This is not a new technology. The Germans ran their war machine on it with the technology of the 1940s; just think what we could do today.

Power from Coal Gas. This article by John Allen from the Vision Engineer Web site provides an overview of coal gas and its uses. Access: http://www.visionengineer. $\mathrm{com} / \mathrm{mech} /$ coal_gas.shtml.

\section{Diesel}

Diesel oil is slightly less re ned than gasoline. It is always oily and not liquidy like gasoline. This slight lack of re nement gives us more bang for our buck or at least our barrel. Long the property of heavy equipment, industrial use, and railroads, technological advancements make it viable for automobiles even small ones.

How Diesel Engines Work. This article from the HowStuffWorks Web site (excellent for basic information on anything technical), provides a good example of how diesel engines work. Access: http://auto.howstuffworks.com/diesel1.htm.

\section{Heavy oil}

Heavy oil is not the liquid we re used to. It is a form of petroleum and has a much more solid form. It looks like silly putty with coffee grounds. Native Americans used to caulk their canoes with it. With energy prices high, heavy oil remains economically feasible.

What is Heavy Oil. This page from the Oil eld Technical Society (OTS) Heavy Oil

Gary L. Parsons is a reference and engineering librarian at Florida Atlantic University, e-mail: parsons@fau.edu (C) 2005 Gary L. Parsons 
Science Center provides more information on heavy oil. Access: http://www.lloydminsterheavyoil.com/whatislaunch.htm.

\section{Internal combustion engine}

Like its petroleum counterpart, this bit of technology has served us well over the past century (and beyond). It comes in all sizes and serves countless types of vehicles and power needs.

How Car Engines Work. This installment from the HowStuffWorks series provides some good information about how your car engine functions. Access: http://auto.howstuffworks.com/engine3.htm.

\section{Natural gas}

Natural gas is a clean-burning alternative fossil fuel that we have in abundance in North America.

The Natural Gas Vehicle Coalition. Natural gas has many uses, including that of powering cars and other vehicles as this site shows us. Natural gas is already in wide use in eet cars, buses, and other vehicles that do not stray too far from the fuel source. Access: http://www.ngvc.org/ngv/ngvc.nsf

Natural Gas Supply Association. This educational Web site from the Natural Gas Supply Association provides additional information on topics related to natural gas and strives to present an unbiased learning tool for students, teachers, industry, media, and government. Access: http://www.naturalgas.org/.

\section{Nuclear}

Nuclear power works. We nd that if we approach this source without the usual irrationality that nuclear power provokes, it is a viable and economically competitive alternative to coal and oil for a large-scale power generation.

How Nuclear Power Works. The folks at HowStuffWorks have good, basic explanations and diagrams of how a nuclear power plant works. Access: http://people.howstuffworks.com/nuclear-power.htm.

\section{Oil}

Whatever else can be said about oil, it works. It powers a multitude of engines and is useful in all types of situations. The problem is supply, and not just pure supply (some now think that petroleum is a natural geological phenomenon), but supply outside of politically unstable regions.

How Oil Drilling Works. This site from HowStuffworks provides information on the basics of the oil business from exploration to extraction. Access: http://www.howstuffworks.com/oil-drilling1.htm.

\section{Energy transition technology}

These are alternative energy sources that are ready for use or in serious development, with just a little push to get them to the magical status of commercially reliable.

\section{Alcohol}

Alcohol and driving do mix in the fuel tank. Alcohol is a viable fuel for vehicles. It was, in fact, the original choice of fuel by Henry Ford. Alcohol can be used in an internal combustion engine with little modi cations. Many countries have been using it for years. It burns cleaner than gasoline but has a little less octane, requiring more of it to stay even with the power of gasoline. Nevertheless, it is a renewable fuel, and it works.

Henry Ford, Charles Kettering and the "Fuel of the Future." This essay by Bill Kovarik covers the history, pros, and cons of alcohol as a fuel source. Access: http://www. radford.edu/ wkovarik/papers/fuel.html.

\section{Biofuels}

It is possible to make fuels out of plants and plant waste. Two good sites from the State of Oregon and Uncle Sam (The Department of Energy has good, solid information on its Web page on alternatives) give excellent explanations of how the process works and what it can do for us. Biofuels claim to be the best renewable source for liquid fuels that we have right now. Fuels used now are ethanol, methanol (alcohol), and biodiesel.

Oregon Department of Energy's Biomass Energy Page. Access: http://www. energy.state.or.us/biomass/BiomassHome. htm

U.S. Department of Energy's Energy Efficiency and Renewable Energy Bio- 
mass Program. Access: http://www.ott.doe. gov/biofuels/

\section{Compressed air}

Want an abundant energy source? How about running our vehicles on air? It has already been done.

MDI (Moteur Developpment International). French company MDI has come up with a CAT (compressed air technology) vehicle. It runs on tanks of compressed air and can run for 120 miles or up to 10 hours. It s a modern start. Access: http://www.theaircar.com/howitworks.html)

The Pneumatic Options Research

Library. This site shows examples of many cars running on air . . . in the late 1800s! Access: http://aircaraccess.com/index.htm.

\section{Hemp}

Hemp is an interesting plant that can be use for food, clothing, paper, and fuel. It is grown everywhere in the world except the U.S. This provides a eld day for conspiracy writers, but it is probably due to hemp s familial links to the cannabis (marijuana) family.

Hemp as Biomass for Energy. Hemp supporters have a strong Web presence. The Learn More about Hemp site, is the best one that I found that explains hemp s potential as a fuel. Access: http://www.artistictreasure. com/learnmorecleanair.html.

\section{Hydrogen}

If the U.S. is running out of a fuel source, why not switch to hydrogen, the most abundant element in the universe? We can, but there is a problem because you cant drill or mine hydrogen. You have to create it. It is usually used as a natural gas, and storage is a problem for the liquid form that vehicles require (high pressure and extreme cold temperatures). These are basically infrastructure problems. Hydrogen already powers vehicles that dont venture from their sources (buses, urban eets), but what about longer distances? The infrastructure issues are solvable, and many companies and inventors claim that they already have the answer.

Hydrogen Now. Roger Billings claims to have solved the fuel cell problem in the 1970 s and now can easily convert internal combustion engines to fuel cell use. A press release on the Hydrogen Now Web site details his claims (http://www.hydrogennow. org/HNews/PressReleases/Billings/Billings1. htm). The site contains extensive information on hydrogen and its uses, including news, facts, and links. Access: http://www.hydrogennow.org/

U.S. Department of Energy's Energy Efficiency and Renewable Energy Hydrogen, Fuel Cells, and Infrastructure Technologies Program. This site discusses the hydrogen economy and how fuel cells work. Access: http://www.eere.energy.gov/ hydrogenandfuelcells/.

\section{Fuel cells}

Related to hydrogen energy, fuel cells are the most commonly agreed upon method of using hydrogen. A fuel cell is an electrochemical device, like a battery, but designed for continuous replenishment of the reactants involved. It creates electricity from an external fuel, while a battery is discarded when drained.

Advanced Vehicles and Fuel Research. A simple but effective illustrated explanation of fuel cells is found on this site from the National Renewable Energy Laboratory. Access: http://www.nrel.gov/vehiclesandfuels/whatis_fuelcell.html.

\section{Solar}

Let us not forget solar, one of the oldest of the new technologies. Not that useful yet in transportation or industrial use, solar energy has found a niche in the home. Solar is a key factor in cutting utility bills and is the key to the ef cient and environmentally sound passive solar homes that we have now.

The Florida Solar Energy Center. This site for the University of Central Florida s Florida Solar Energy Center provides information on the application and use of solar energy. Access: http://www.fsec.ucf.edu/.

\section{Steam}

Back to the future. Another alternative solution is the original fuel for mechanized ve- 
hicles: steam. Steam is an old technology. It was used for toys in the ancient days. There is even a famous picture of a steam car in the 1770s internal combustion and diesel did not appear until the late 1800s. This car, known as the Cugnot vehicle, was little more than a buckboard with a boiler in front (sadly, the picture shows it being driven into the side of a building but it was powered and it ran). Steam cars are safe, easy to maintain, and run on a variety of fuels.

Steam Car FAQs. Details of the advantages of steam cars are eshed out on the Steam Automobile Club s FAQ page. Access: http://ghlin2.greenhills.net/ apatter/steamfaq.html.

Mike Brown Solutions. Another good source for steam and alcohol is this site by steam advocate, Mike Brown. It gives good, practical advice on steam and other resources and compares gasoline and alcohol fuels. Access: http://www.mikebrownsolutions. $\mathrm{com} /$.

\section{Stirling}

The Stirling is one of a series of devices that is a heat engine that operates on any fuel. This futuristic technology (invented in 1816) is in use but is not widespread.

Stirling Engine Home Page. This site explains the history and use of the Stirling Engine. Access: http://www.bekkoame. ne.jp/ khirata/indexe.htm.

\section{Tidal}

Tidal power is just that. It generates power twice a day from the change in the ocean $s$ tides. Tidal power will not, of course, do the Midwest much good, but it can help relieve pressure on the grid in the heavily populated coastal areas. It creates power in a similar fashion as regular hydroelectric power plants (and can use much of the same technology and equipment).

Andy Darville's Science Site Tidal Power. This section of Andy Darvilles Web site gives good details on tidal power s workings, advantages, and disadvantages. Access: http://www.darvill.clara.net/altenerg/tidal. htm\#adv.

Hydroelectric Power How it Works.
As I have just alluded to hydroelectric power, I must mention this site from the U.S. Geological Survey, which explains how dams and the hydroelectric process works. Access: http:// ga.water.usgs.gov/edu/hyhowworks.html

\section{Wind}

From compressed air we move to the least compressed air of all ordinary wind. While not useful for transportation, wind generators can help relieve stress on the power grid and other forms of stationary power generation.

National Wind Technology Center Wind Resource Information. This is a good page with moving graphics that show how wind technology works. Access: http://www. nrel.gov/wind/animation.html.

\section{To boldly go ...}

The following are possibilities for future developments. These items usually exist in experimental or toy form, but are not available in workable models yet.

\section{Cold Fusion}

There was a lot of hype about cold fusion in 1989 when this invention was announced. Well, an intrepid band of researchers from all over the world has kept up with it, and, guess what? It works. Cold fusion (actually the popular name for LENR-CANR: Low Energy Nuclear Reaction-Chemically Assisted Nuclear Reaction) has an extreme Web presence, mostly of a cionados and a few debunkers.

Wikipedia-Cold Fusion. The closest thing I could nd to a how to site on cold fusion is in the Wikipedia. Mainstream journals are beginning to write about it and the U.S. Energy Department is initiating a second look. Could we nally realize Jules Vernes dream of re from water? Access: http:// en.wikipedia.org/wiki/Cold_fusion.

\section{Free Energy}

Free energy refers to a whole family of devices, mostly magnetic in nature, that provide fuelless propulsion. The muse of this movement (and, to a degree, the entire alternative energy movement) is 19th-century inventor Nikola Tesla. These devices could 
signi cantly change society whenever they get them beyond the laboratory stage. Not without their critics, a cionados of Free Energy have a large Web presence.

TheLivingWeb.net-Free Energy. Zero Point. Cold Fusion. This site has a decent overview of all things related to free energy. Access: http://www.thelivingweb. net/free_energy.html.

\section{Journals}

Extraordinary Tecbnology. This journal is from the Tesla Tech Group, an outgrowth of the defunct Tesla Society. Most articles, therefore, are on energy development with a pro-free energy bias. Quite readable generally, articles frequently discuss and use hard science, including formulas, mathematics, etc. Access: http://www.teslatech.info

Free Energy News. Those who study this eld of energy have their own online news outlet. Access: http://freeenergynews. com/newstuff/.

Nexus. An easier read than the previous entries, this magazine covers energy topics, criticisms of current medicine, and corporate globalism. It occasionally strays into UFOs and New Age-type topics. Nexus is a refreshing bit of alternative viewpoints. Access: http://www.nexusmagazine.com.

\section{Organizations}

The Alternative Energy Institute.

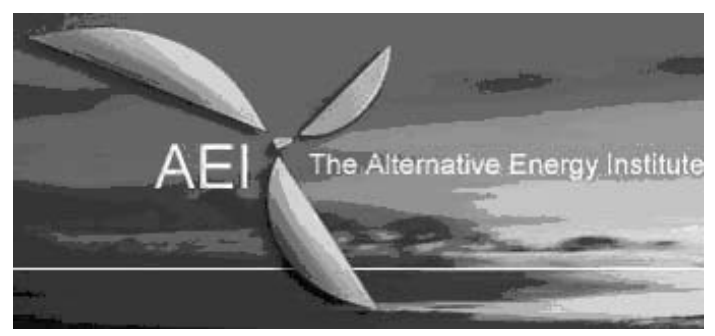

Image courtesy of Alternative Energy Institute

Most of the organizations I have come across are basically trade organizations or other advocates. These groups, as I have shown, provide basic, solid information on their product. The Alternative Energy Institute is the one I like the best. While it is an advocacy group, it does present essays on the pros and cons of all kinds of energy sources, from the basics to the future. Access: http://www. altenergy.org/

\section{Miscellaneous}

Here are a few sites that did not $t$ into the previous categories of resources but are bene cial nonetheless.

Renewable Energy Resources Research Guide. This guide is just that: a resource page giving the facts and news items on a variety of alternative energy sources. Access: http://www.aresearchguide.com/energy.html.

The Source for Renewable Energy. This site provides access to more than 8,000 businesses engaged in the alternative energy eld right now. Access: http://energy.sourceguides.com/index.shtml.

By Design. This link gives basic descriptions of several of the fossil fuels. Access: http://www.bydesign.com/fossilfuels/links/ html/oil.html.

Department of Energy (DOE). The DOE is getting some good, useful information on its Web page. Access: http://www.energy. gov/engine/content.do.

Institute for Ecolonomics. Dennis Weaver, who played Marshall McCloud on the television series McCloud, has long been a leader in the environmental movement. He is now a player in the alternative energy movement. His Institute for Ecolonomics is a major educational force in this eld. He also organizes drives (some up the coast in California, some across county) of alternative fueled vehicles. Called Drives to Survive (http://www.drivetosurvive.info), his alternative fueled cars already do just that. Absolutely worth a look. Access: http://www. ecolonomics.org/.

Yahoo. Can any topic be researched without the ubiquitous Yahoo? Access: http:// dir.yahoo.com/Science/Energy/, http://dir. yahoo.com/Science/Alternative/, http://dir. yahoo.com/Recreation/Automotive/Alternative_Fuel_Vehicles/. $\boldsymbol{n}$ 